Abstracta Iranica Abstranica

Revue bibliographique pour le domaine irano-aryen

Volume 32-33 | 2013

Comptes rendus des publications de 2009-2010

\title{
Daniel T. Potts. Mesopotamia, Iran and Arabia from the Seleucids to the Sasanians
}

\section{Florence Jullien}

\section{(2) OpenEdition \\ 12 Journals}

Édition électronique

URL : http://journals.openedition.org/abstractairanica/40878

DOI : 10.4000/abstractairanica.40878

ISSN : 1961-960X

\section{Éditeur :}

CNRS (UMR 7528 Mondes iraniens et indiens), Éditions de l'IFRI

\section{Édition imprimée}

Date de publication : 1 décembre 2013

ISSN : 0240-8910

\section{Référence électronique}

Florence Jullien, «Daniel T. Potts. Mesopotamia, Iran and Arabia from the Seleucids to the Sasanians », Abstracta Iranica [En ligne], Volume 32-33 | 2013, document 344, mis en ligne le 01 juillet 2016, consulté le 26 septembre 2020. URL : http://journals.openedition.org/abstractairanica/40878 ; DOI : https://doi.org/10.4000/abstractairanica.40878

Ce document a été généré automatiquement le 26 septembre 2020.

Tous droits réservés 


\title{
Daniel T. Potts. Mesopotamia, Iran and Arabia from the Seleucids to the Sasanians
}

\author{
Florence Jullien
}

\section{RÉFÉRENCE}

Daniel T. Potts. Mesopotamia, Iran and Arabia from the Seleucids to the Sasanians. Aldershot, Ashgate, 2010, 372 p. (Variorum Collected Studies Series CS 962)

Ce volume réunit vingt articles sur une période allant de l'avènement de l'empire achéménide à l'arrivée de l'islam, publiés entre 1988 et 2008. Deux d'entre eux concernent le christianisme nestorien en Arabie orientale, le Beth-Qatrayē des sources syriaques (XIV, 2008 et XIX, 1994). Une des stèles gravées retrouvées à Bahrain lors de la campagne de fouilles de 1991-1993 présente plusieurs symboles (étole de diacre, grappe de raisin et colombe) sur lesquels la critique restait prudente quant à leur caractérisation chrétienne. L'A. revient sur l'interprétation de cette stèle à la lumière des découvertes archéologiques récentes faites à al-Maqsha et à Shakhura (Bahrain). On sait que l'ancrage du christianisme dans la région est ancien puisque l'évêché de Mashmahig dans la péninsule est attesté dès le premier synode de l'Église syroorientale, au tout début $\mathrm{du} \mathrm{V}^{\mathrm{e}}$ siècle. Le second article a trait aux découvertes de deux petites croix retrouvées au Jebel Berri, qui présentent des ressemblances stylistiques avec les croix d'al-Qousour/Failaka et des parallèles artistiques avec l'art copte et éthiopien. 


\section{AUTEURS}

\section{FLORENCE JULLIEN}

EPHE, Paris 